\title{
Fractura de fémur en displasia congénita de cadera
}

\author{
Fracture of femur in congenital hip dysplasia
}

Rafael Pichardo-Rodriguez ${ }^{1,2,3,4, a}$ José E. Hernandez-Chicas ${ }^{3,4, b}$

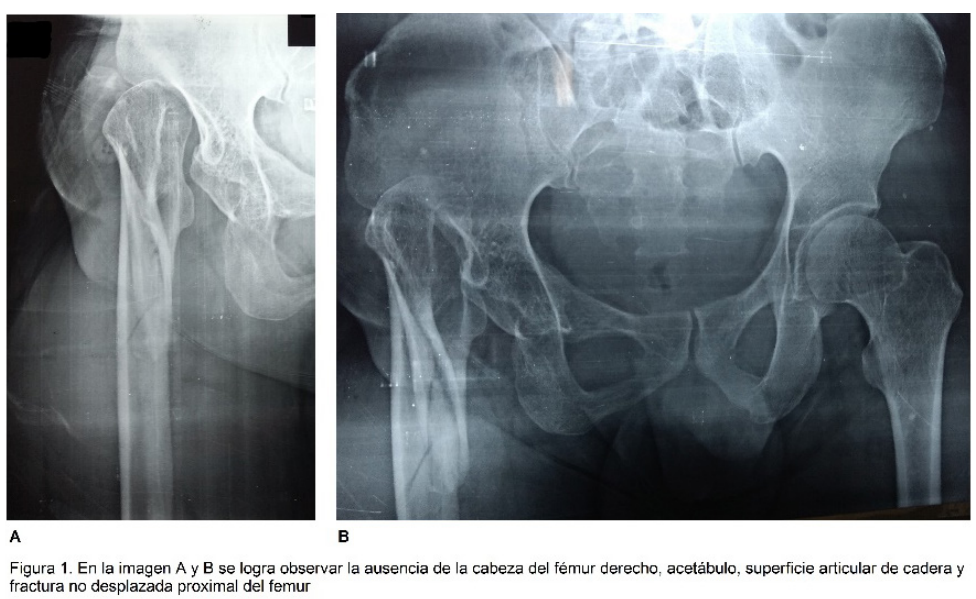

Varón de 30 años con antecedente de displasia congénita de cadera no tratada, diagnosticada a los siete meses de vida. Acudió con historia de 8 horas refiriendo caída de un metro de altura, desde un camión. Al apoyar la caída sobre el miembro inferior derecho le originó dolor, deformidad, acortamiento de la extremidad, aumento de volumen de muslo derecho e impotencia funcional. Acudió a una clínica, donde le tomaron radiografía de pelvis y fémur derecho (figura 1), pero no contar con recursos económicos, acudió a nuestro hospital. En el examen físico se evidenció aumento de volumen a nivel del muslo derecho, doloroso a la palpación, acortamiento de extremidad, rotación externa y movimientos limitados. Se procedió a estabilizar la fractura y programación para cirugía.

A 30-year-old male with a history of congenital hip dysplasia untreated, diagnosed at seven months of age. He came with an 8-hour history of falling one meter high, from a truck. By supporting the fall on the lower right limb, it caused pain, deformity, shortening of the limb, increase of right thigh volume and functional impotence. He went to a local clinic, where he had a pelvic and right femur x-ray (Figure 1), but he did not have the financial resources, he went to our hospital. Physical examination revealed increase in volume at the right thigh, painful on palpation, shortening of the limb, external rotation and limited movements. The fracture and surgical programming were stabilized.

\section{Correspondencia:}

Rafael Pichardo-Rodriguez

Dirección: Av. Javier Prado Este 3028 - San Borja

Correo electrónico: rafael_martin1352@hotmail.com

Teléfonos: 05113593336/ 0511987757675

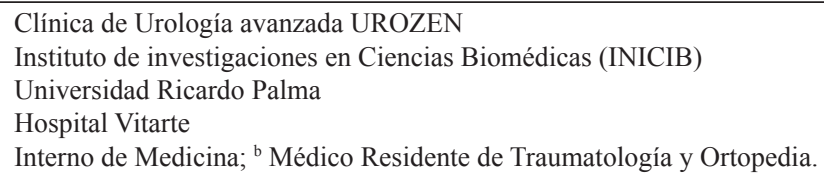

